\title{
The effectiveness of the use of microbiological preparations when interacting with seed stocks of the genus Prunus $L$.
}

\author{
Anna Kuznetsova*, Sergey Gridnev, and Anna Drygina \\ North Caucasian Federal Scientific Center of Horticulture, Viticulture, Winemaking, st. 40th Let \\ Pobedy 39, 350072, Krasnodar, Russia
}

\begin{abstract}
An important element of increasing the efficiency of production of high-quality planting material of fruit crops according to the criteria of environmental management, resource conservation and productivity is the use of adaptive, technological rootstocks, as well as microbiological preparations that are environmentally friendly and multifunctional. They stimulate plant growth by changing their hormonal status, act as fungicides, as bio protectors, forcing the plant turn into its defense mechanisms, as bio fertilizers that promote the absorption of atmospheric nitrogen by plants, hard-to-reach forms of phosphorus, a number of trace elements, have an antistress effect, etc. To control the process of obtaining seedlings of the highest quality category, it is necessary to study the living system "plantmicrobiological preparation-environment”. As a result of this research, it was found that the high temperature background in combination with severe drought, observed during the years of research, adversely affected both the development of rootstocks in the first field of the nursery, and the effect of microbiological preparations. When developing resource-saving elements in technology - the selection of genotypes and microbiological preparations for growing rootstocks, bypassing the school of seedlings, form 3-106 was highlighted, when using the preparation Pseudobacterin-2. Found a regularity - a positive interaction in the conditions of the Ust-Labinsk district of OLL "Experimental Nursery (EN) named after K.A. Timiryazev" seedlings of rootstocks for sweet cherry and cherry, of different origin, and the preparation Pseudobacterin-2. In conditions of high temperatures in the spring-summer period, the isolated preparation increased the germination capacity and the yield of high-quality planting material.
\end{abstract}

\section{Introduction}

For the development of horticulture in the south part of Russia, planting material of high quality and varietal composition is required. A large number of zones, subzones and micro zones, which are characterized by different soil and climatic conditions, distinguishes Krasnodar Territory. For example, if in the conditions of the Goryacheklyuchevskoy district in the village of Baku, it is impossible to grow cherries, sweet cherries on rootstocks seedlings

\footnotetext{
*Corresponding author: anpalkuz@mail.ru
} 
of antipka and on forms derived from them, then in the northern regions of the Krasnodar Territory (districts of Ust-Labinsky, Kushchevsky), this rootstock is precisely the best to grow gardens on it, i.e. on selected winter-hardy, drought-resistant forms of Magaleb cherry (Prunus mahaleb). As shown by numerous studies, the selection of genotypes for certain environmental conditions where plants feel good, i.e. show resistance to stressors, most often manifested in these conditions, is one of the elements of resource-saving technologies [1]. Another element of this direction in agriculture is the use of bio agents based on strains of bacteria, fungi, etc., obtained as a result of modern methods of biotechnology and selection [2].

With the modern agricultural production, due to violation of the regulations for the use of chemical means of protection, there is often a decrease in the suppressiveness of soils, its biological component. The soil becomes incapable of self-cleaning, and the number of toxinforming species of bacteria and fungi increases [3]. The preservation of microorganisms that play an important role in the plant-soil ecosystem is an important task in crop production [4, 5].

The developed technologies based on the interaction of the systems "plant - external environment", "plant - microbiological preparation - external environment" allow not only to create less energy-intensive production of rootstocks, seedlings and fruit products, but also have a beneficial effect on the production of environmentally friendly products, and in many situations even restore soil fertility [6-8].

The study of these interactions, by studying the reaction of plants to microbiological preparations, are of both applied and fundamental nature and are of interest for genetics, microbiology, phytopathology, and general biology.

The purpose of our research is to study the interaction of microbiological preparations and seed stocks in terms of their development and growth in the first field of the nursery.

\section{Materials and methods}

The research used following forms and rootstocks of sweet cherry and cherry: antipka (Prunus mahaleb), cherry seedlings (Prunus avium), Drogan yellow, VP-1, OVP-4 (VNIISPK); 10-14, 10-18, 3-73, 3-61, 3-106, 3-76, 10-11, 5-34, 3-115, 11-15 - derived from East Asian cherry species, created in FSBSI NCFSCHVW.

The effect of the following bacterial preparations on seed germination and biometric parameters of rootstocks in the first field of the nursery was studied: Fitosporin M (Bacillus subtilis), BFTIM KS-2 Zh (Bacillus amyloliquefaciens KS-2) (KS-2), Biofungicide (Bacillus subtilis B-10) (B-10), Pseudobacterin-2 (Pseudomonas aureofaciens) (PS-2); and fungi Glomus sp. The seeds in the "control" variant were treated only with a solution of potassium permanganate after cleaning the seeds from the pulp. The rest of the seed material of the sweet cherry and cherry rootstocks was soaked in an additional $2.5 \%$ working solution before stratification. Exposure time - up to 20 minutes. The Preparations were provided by Biotehagro LLC (Timashevsk).

The experience was laid on the basis of the nursery of OLL "EN named after K.A. Timiryazev" (Ust-Labinsky district) in the Kuban fruit zone. The structure of variability of the considered traits was studied using analysis of variance [9]. For the calculations, the statistical package StatSoft Statistica 10.0 was used. The studies were carried out according to the standard methods for the variety study of fruit crops. 


\section{Results and Discussions}

To study the spectrum of action of microbiological preparations in the nursery, seed stocks of the genus Prunus L., of various origins, were taken into research (Table 1). The studies used microbiological preparations based on Bacillus amyloliquefaciens KS-2 (BFTIM KS-2 Zh), Bacillus subtilis B-10 (Biofungicide, Fitosporin M), Pseudomonas aureofaciens (Pseudobacterin-2), Glomus sp. They were taken into the experiment according to the literature data and according to the indications obtained from preliminary studies [10-12].

Table 1. Origin of rootstock forms

\begin{tabular}{|l|l|}
\hline Rootstock & Origin \\
\hline Antipki & Prunus mahaleb \\
\hline $\begin{array}{l}\text { Seedlings of different forms of sweet } \\
\text { cherries }\end{array}$ & Prunus avium \\
\hline Drogan yellow & Prunus avium \\
\hline VP-1 & Prunus cerasus $x$ P.maackii \\
\hline OVP-4 & Prunus cerasus $x$ P.maackii \\
\hline $11-15$ & Cerasus lannesiana №2 $\times$ Franz Joseph. \\
\hline $10-14$ & Cerasus incisa $\times$ Polyanka \\
\hline $10-18$ & Cerasus incisa $\times$ Polyanka \\
\hline $3-73$ & Cerasus lannesiana №2 $\times$ Franz Joseph \\
\hline $3-61$ & Cerasus lannesiana №2 $\times$ Bigarro of Oratovsky \\
\hline $3-106$ & Cerasus lannesiana №2 $\times$ Franz Joseph. \\
\hline $3-76$ & Cerasus lannesiana A 24 \\
\hline $10-11$ & Cerasus lannesiana x Polyanka \\
\hline $5-34$ & Cerasus canescens $\times$ Prunus avium \\
\hline $3-115$ & Cerasus cerrulata $\times$ Polyanka \\
\hline
\end{tabular}

The environmental friendliness of microbiological preparations makes agricultural producers increasingly pay attention to them. They act as fungicides, are able to synthesize a number of antibiotics that suppress the growth of phytopathogenic fungi, and affect the resistance of plants by indirectly improving the rhizosphere. Promote the growth and development of plants, including through the production of phytohormones and the ability of microorganisms to increase the amount of nutrients and physiologically active compounds available to plants $[13,14]$. They carry out molecular interactions, exchange of metabolites and their transformation [15]. They increase the biological potential of plants, thanks to the mechanisms of symbiotic interaction; reduce the harmful effects of herbicides and chemical pollutants.

A number of studies have noted facts that are important for nursery growing - treatment with strains of rhizosphere microorganisms of some genera stimulates an increase in the percentage of germination of seeds of agricultural crops, the rate of germination and the average time of germination $[16,17]$. However, since these are living organisms and a number of data obtained show that the effectiveness of these preparations largely depends on environmental conditions (soil and climatic conditions) for the recommendations of specific drugs, it is necessary to conduct tests in specific conditions. [18].

FSBSI NCFSCHVW has an extensive collection of rootstocks, both clonal and seed, obtained from other scientific institutions and created as a result of distant hybridization and targeted selection for coccomycosis resistance using biotechnological methods. These forms are resistant to fungal diseases of the leaves and have a much smaller crown than that of antipka seedlings and cherry seedlings, which suggests a significant decrease of length of the trees grafted on this forms

We studied the effect of microbiological preparations on the percentage of high-quality seed material in the first field of the nursery in OLL "Experimental Nursery named after K.A. 
Timiryazev". Such work has a great interest, since development of a technology for the production of low-growing forms of rootstocks for sweet cherry and cherry, bypassing the stage of growing them at the seedling school, significantly speeds up and reduces the cost of the production of demanded planting material. Studying the reaction of 15 rootstocks of various origins to the preparations, the selection of technological rootstocks capable of multiplying under such conditions was carried out at the same time.

According to the results of long-term studies, a significant effect on the percentage of rootstocks output was noted.

During the research period, the growth and development of plants were accompanied by the main stress factors of the growing season - high average ten-day, as well as maximum air temperatures exceeding the average long-term values (Fig. 1, 2).

The most critical year - 2018, was characterized by a significant deviation of meteorological parameters from the average long-term values: against the background of extremely uneven precipitation, as well as severe drought in the second half of summer. A significant excess of the average and maximum air temperature was observed.

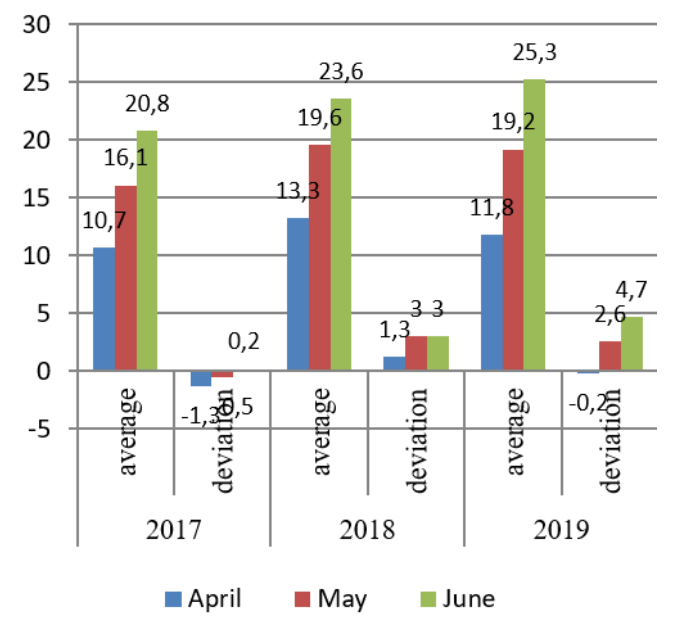

Fig. 1. Average air temperature and its deviation from long-term data for 2017-2019 (Ust-Labinsky district)

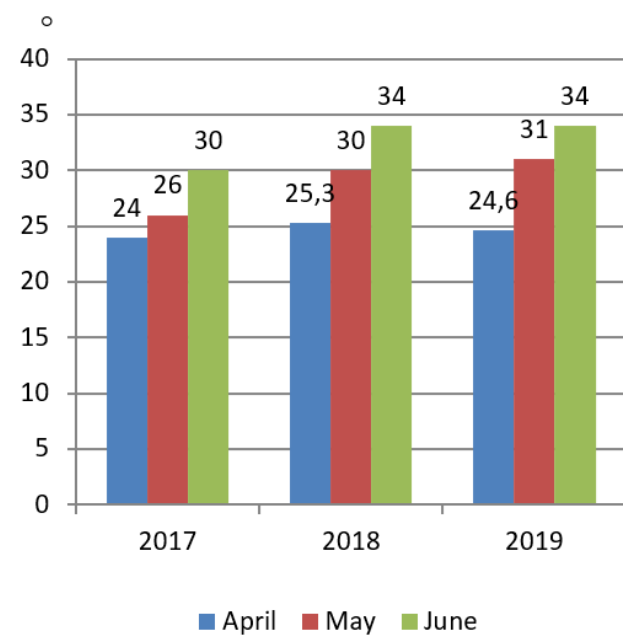

Fig. 2. Maximum air temperature in the period 2017-2019 (Ust-Labinsky district) 
In 2017, the largest number of germinated seeds, 40\% of those were obtained during treatments with Pseudobacterin-2 on average for all variants, which is 2.3 times higher than the control values. However, variety-specificity was visible. The greatest positive effect on this indicator was also noted in the interaction of genotypes 10-14 and 3-61 with Glomus sp., Seedlings VP 1 and antipka with KS-2, 3-106 with the preparation Fitosporin M (Fig. 3). The best under these conditions in terms of the number of seedlings were marked rootstock forms 3-106 (70\%), 3-73 (70\%), 5-34 (63\%), 3-115 (58\%).

In the conditions of drought and high temperatures in 2018 during the spring-summer period, a positive effect of the preparations BFTIM KS-2 Zh, Glomus sp., Pseudobacterin-2 on the germination of seed material was established, an increase of $1.8-2.4$ times was noted relative to the control. Biofungicide (Bacillus subtilis $B-10$ ) under the extreme conditions of this year (the temperature rise in April relative to the average annual by $1.3^{\circ} \mathrm{C}$, and in May by $3^{\circ} \mathrm{C}$ ), practically did not show itself (Fig. 4).

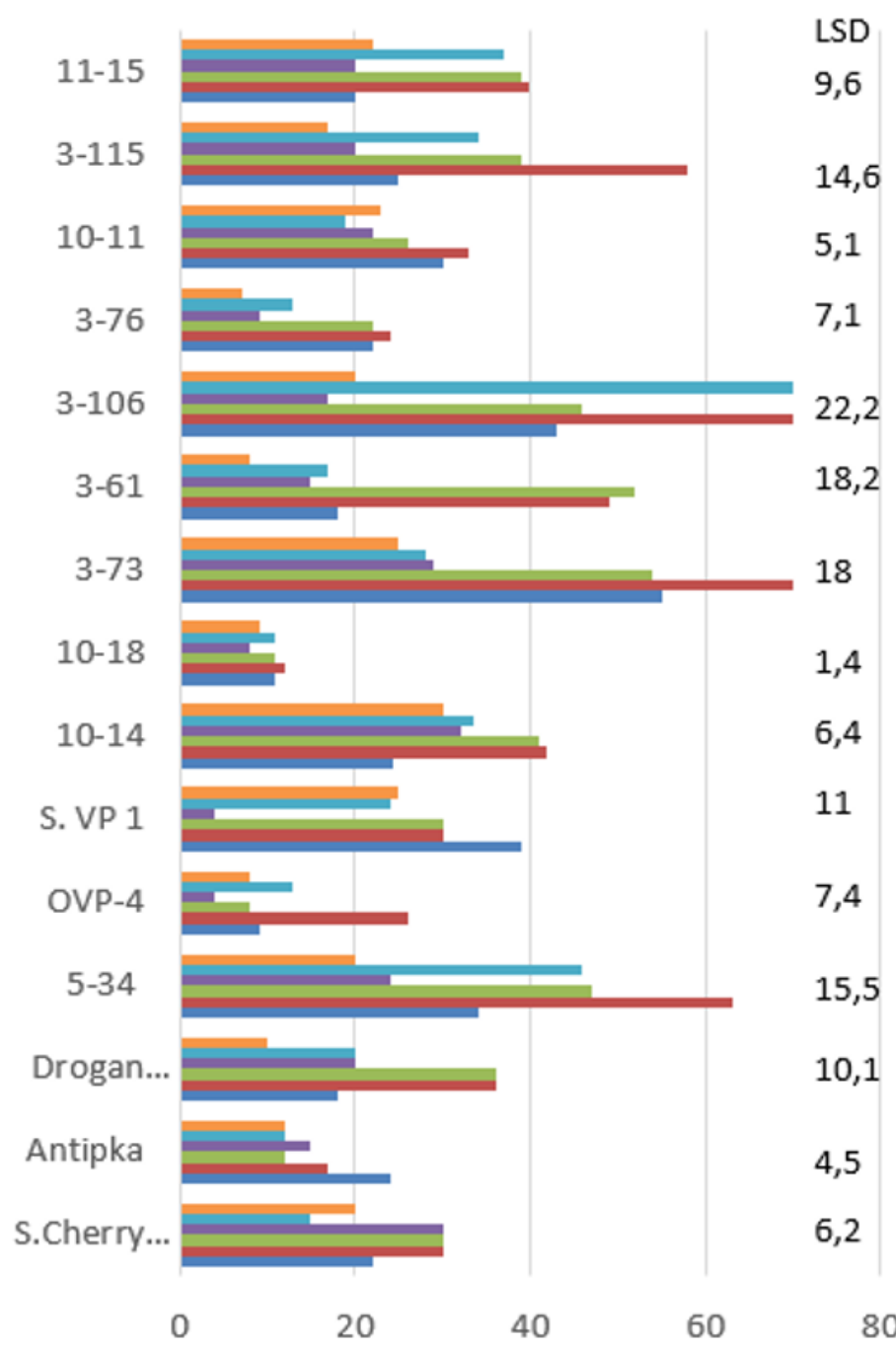

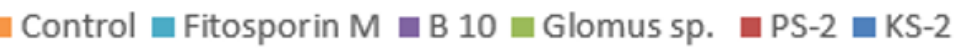

Fig. 3. Seed germination in "EN named after K.A. Timiryazev ", 2017 


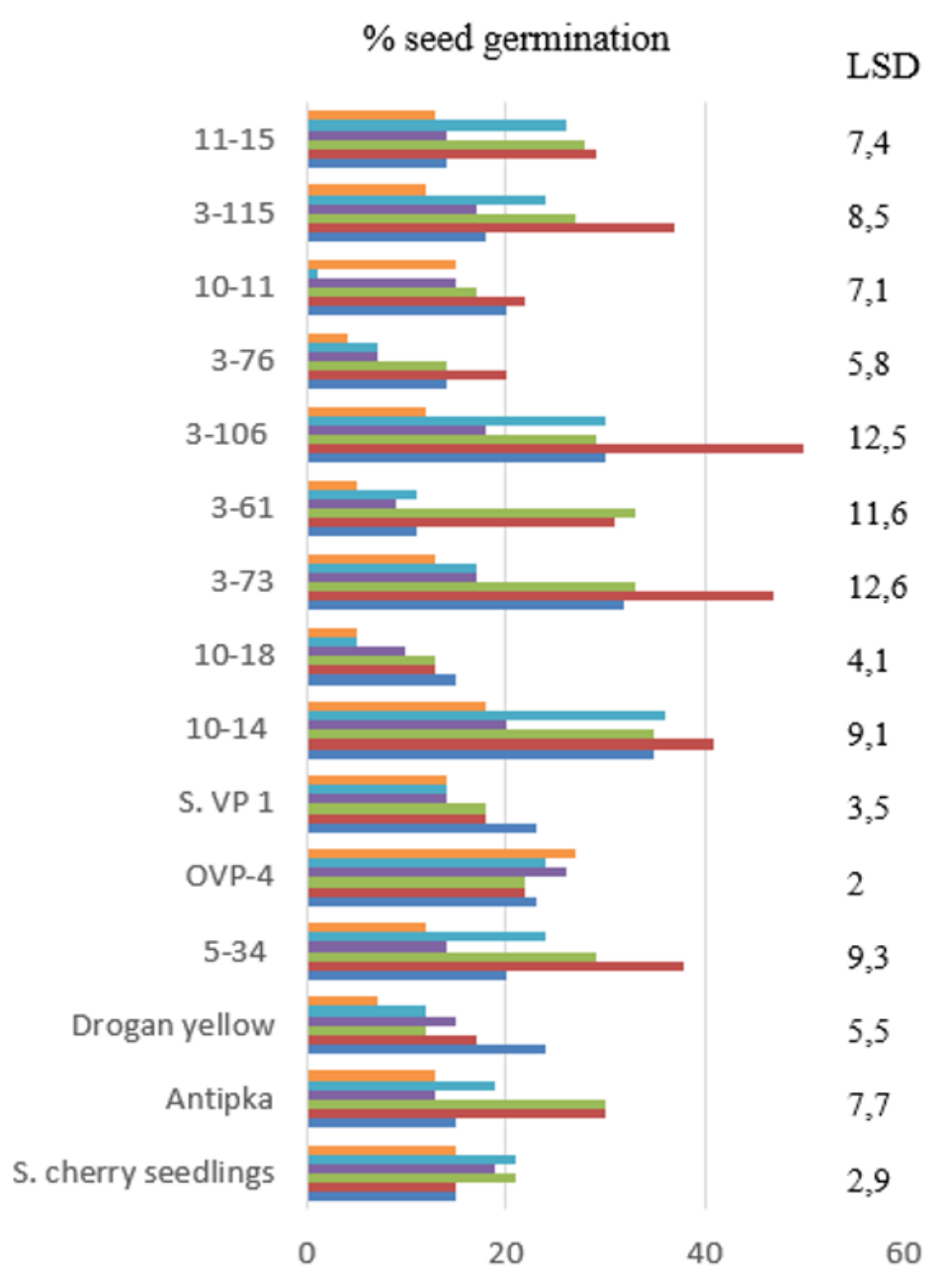

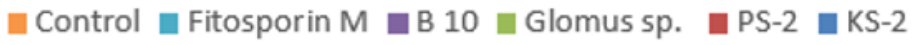

Fig. 4. Percentage of seed germination in "EN named after K.A. Timiryazev ", 2018

Here and in the following table, LSD within a variant when treating one genotype with different microbiological preparations

In 2018, the output of rootstocks for all variants decreased by an average of 1.3 times compared to 2017. The highest percentage of rootstocks in the first field of the nursery was observed in rootstocks 3-106 (50\%), 3-73 (47\%), 10-14 (41\%), 5-34 (38\%), 3-115 (37\%) with using the drug Pseudobacterin-2.

In 2019, due to the high temperatures in May and June, even lower percentage of rootstock yield was noted on average and for a number of forms. However, even during this period, a significant positive interaction of seed stocks of form 3-106 with the preparation Pseudobacterin-2 was noted, the yield of plants per year with extremely high summer temperatures was $89 \%$. 


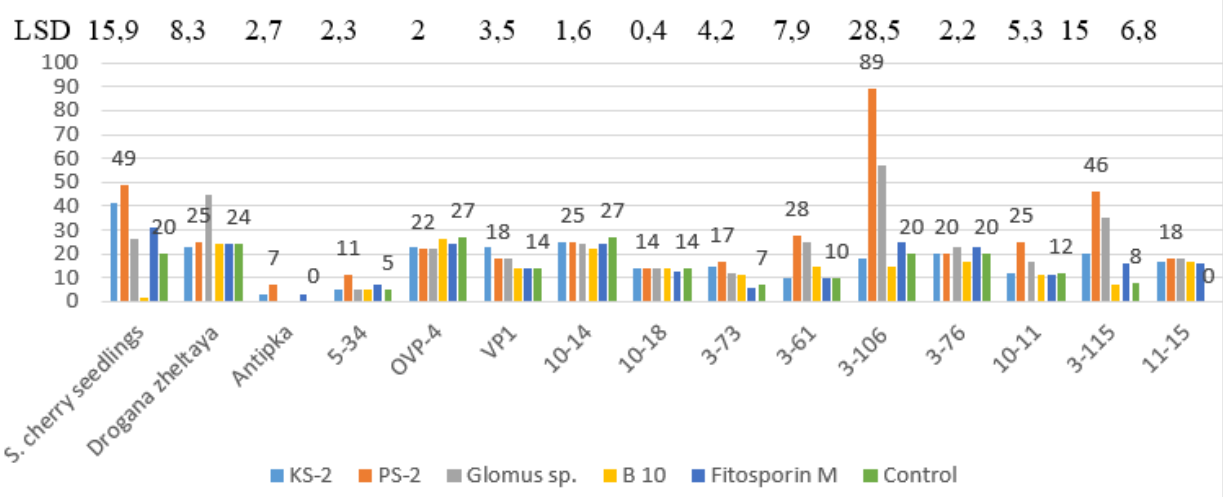

Fig. 5. Percentage of seed germination in OLL "EN named after. K.A. Timiryazev ", 2019

As a result of studies for the period from 2017-2019, which was distinguished by the presence of elevated spring-summer temperatures and prolonged droughts, the drug Pseudobacterin- 2 showed the greatest positive effect on seed germination, and a consistently positive effect was also noted for the drug Glomus sp. (Table 2).

Table 2. Average percentage of rootstock yield in different years when interacting with microbiological preparations in OLL "EN n/a K.A. Timiryazev"

\begin{tabular}{|l|l|l|l|l|l|l|l|}
\hline Year & KS-2 & $\begin{array}{l}\text { Pseudobacte } \\
\text { rin-2 }\end{array}$ & Glomus sp. & B 10 & $\begin{array}{l}\text { Fitosporin } \\
\text { M }\end{array}$ & Control & $\begin{array}{l}\text { LS } \\
D\end{array}$ \\
\hline 2017 & 26,3 & 40,7 & 33 & 17,6 & 26,1 & 17,6 & 8,6 \\
\hline 2018 & 21 & 29 & 24 & 15 & 18 & 12 & 6 \\
\hline 2019 & 18 & 28 & 23 & 13 & 16 & 15 & 5,4 \\
\hline$L S D$ & 5,7 & 9,6 & 7,5 & 3,1 & 7,3 & 3,8 & \\
\hline
\end{tabular}

When studying biometric indicators, the positive effect of KS-2, Pseudobacterin-2, Glomus sp. in 2017, 2018, 2019 on the height, diameter of plants and on the diameter in 2019 of the preparation Fitosporin M. When studying the structure of variability of the studied traits, the influence on the action of microbiological preparations of the soil and climatic conditions of the place of the experiment was established. The share of the influence of this trait in the total variance on the height and diameter of plants was $1.6 \%-4.2 \%$, and a greater effect of microbiological preparations on the height of plants of various genotypes was revealed than on the diameter - up to $47.7 \%$ [18].

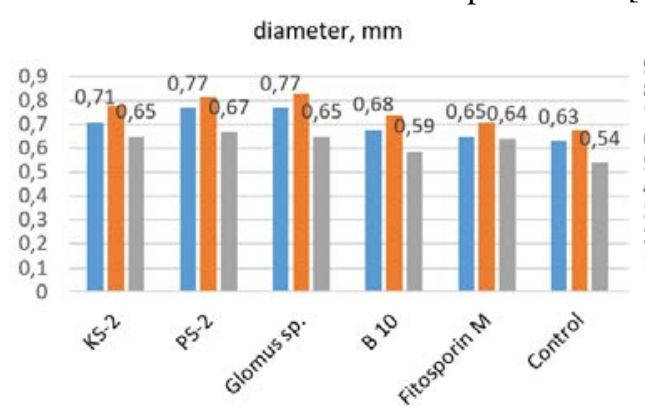

$=2017=2018=2019$

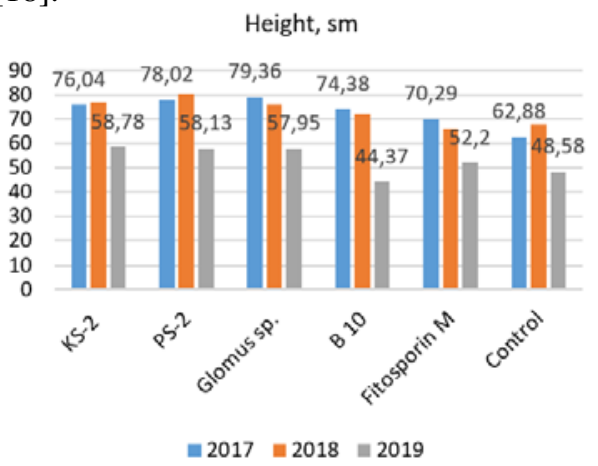

Fig. 6. Influence of microbiological preparations on the diameter and height of rootstocks in the first field of the nursery 
As a result of studying the interactions in the system "microbiological preparationrootstock-environment", a regularity was established - the most stable positive reaction to the yield of standard rootstocks was shown by the preparation Pseudobacterin-2, an increase in this indicator for a number of rootstocks was noted by 5 times relative to the control ones. The preparations Glomus sp., BFTIM KS-2 Zh also had a positive effect on the quality of the rootstocks; their treatment showed an increase in the yield of standard rootstocks by 1.4 times. It should be noted that, in the control variant, almost all rootstocks, due to insufficient branching of the root system, were assigned to the second commercial grade, and plants treated with microbiological preparations were assigned to the first (Fig. 7).

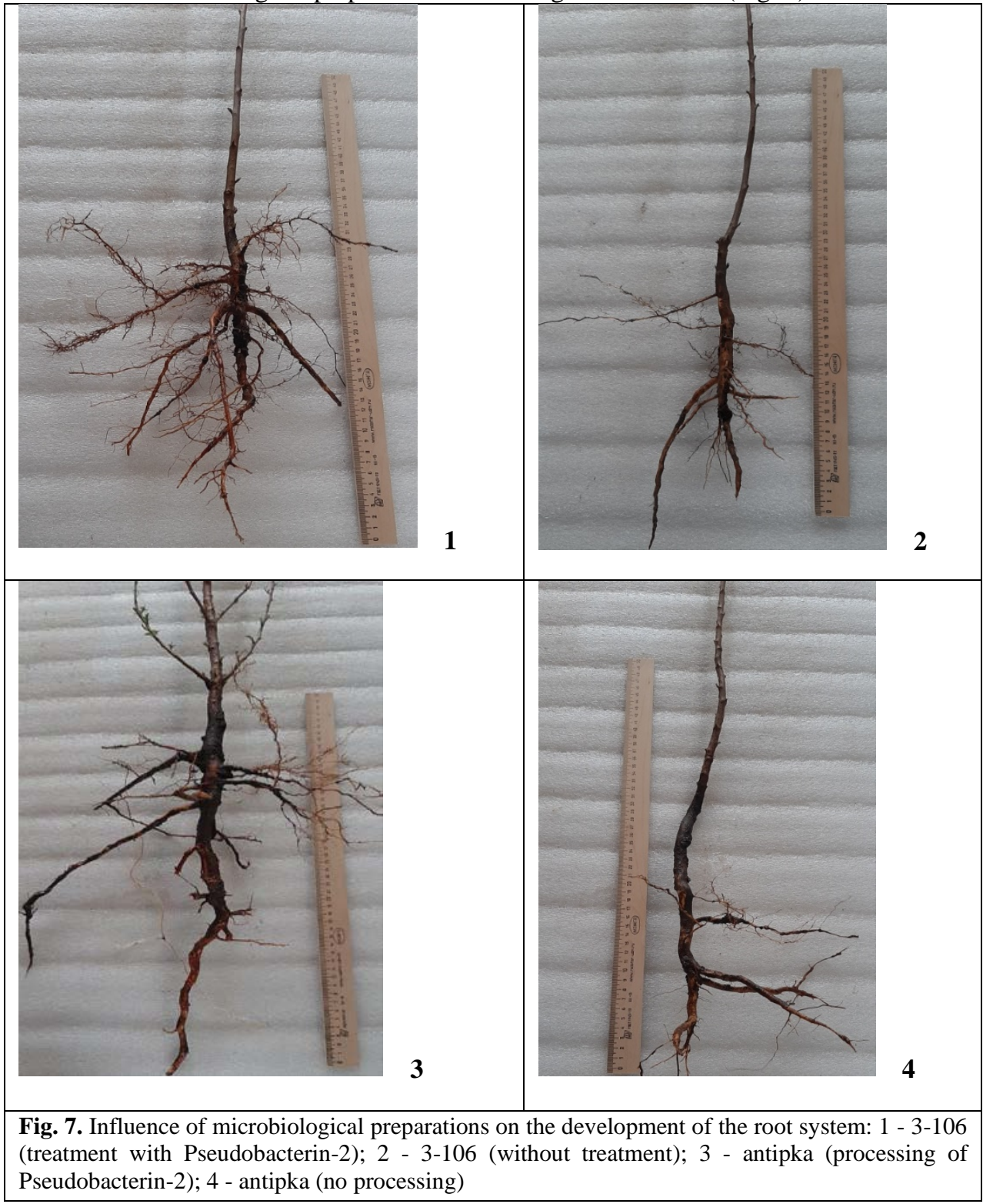

It was found that in the first field of the nursery in the conditions of OLL”EN n/a K.A. Timiryazev "it is profitable to grow stock 3-106, bypassing the school of seedlings, using 
the drug Pseudobacterin-2. When using this rootstock in the given soil and climatic conditions with the proposed element of technology, it was economically proven to reduce the unit cost of seedlings by $15.6 \%$ and increase the profitability of production by $36.8 \%$.

\section{Conclusion}

1. The study of the effect of microbiological preparations on the rootstocks in the first field of the nursery showed the dependence of the studied system on the conditions of the year, the genotypes of plants and their constituents.

2. Revealed a significant positive effect of the drug Pseudobacterin-2 on germination, height, diameter in almost all rootstocks. Marked by years and variety specificity.

3. The most technologically advanced for growing in the first field of the nursery, bypassing the nursery of seedlings, turned out to be a rootstock 3-106, which showed a high germination rate - up to $89 \%$, while interacting with the microbiological preparation Pseudobacterin-2; and also showed a large yield of standard rootstocks up to $80 \%$, even in years with insufficient soil moisture and high spring-summer temperatures.

The study was carried out with the financial support of the Kuban Scientific Foundation and OLL "NE named after K.A. Timiryazev" within the framework of the scientific project № MFI-P-20.1 / 12

\section{References}

1 I.M. Kulikov, A.I. Zavrazhnov, M.T. Upadyshev, A.A. Borisova, T.A. Tumayeva, $\begin{array}{lllll}\text { Sadovodstvo i } & \text { vinogradarstvo, } & 1, & 30-35 & \text { (2007) }\end{array}$ https://doi.org/10.25556/VSTISP.2018.1.10500

2 U. K. Vandana, B. Singha, A.B.M. Gulzar, P.B. Mazumder, Molecular Aspects of Plant Beneficial Microbes in Agriculture, 221-233 (2020) https://doi.org/10.1016/B978-0-12818469-1.00019-5

3 S. Compant, B. Duffy, J. Nowak, Ch. Clément, E. Ait Barka, Appl. and Environ. Microbiol., 71 (9), 4951-4959 (2005) DOI: 10.1128/AEM.71.9.4951-4959.2005 https://aem.asm.org/content/71/9/4951.short

4 B. Kumari, M. A. Mallick, M. K. Solanki, A. C. Solanki, A. Hora, W. Guo, Plant Health Under Biotic Stress, pp 109-127 (2019) https://link.springer.com/chapter/10.1007/978-98113-6040-4_6

5 D.W. Kandula, E.E. Jones, I.J. Horner, A. Stewart, Australasian Plant Pathology, 39. 312-318 (2010) https://link.springer.com/article/10.1071/AP09096

6 I.L. Efimova, Proceedings of the North Caucasus Federal Scientific Center for Horticulture, Viticulture, Winemaking, 17, $76-79$ (2018). https://doi.org/10.30679/25879847-2018-17-76-79

7 A.P. Kuznetsova, Ye.L. Tyshchenko, Trudy Kubanskogo gosudarstvennogo agrarnogo universiteta, 4 (55), 124-128 (2015) https://www.elibrary.ru/item.asp?id=24912732

8 W. Zhou, S. Qin, D. Lyu, P Zhang, Archives of Agronomy and Soil Science, 61 (3), 361-370 (2015) https://doi.org/10.1080/03650340.2014.935346

9 D. Eszergár-Kiss, B. Caesar, Transportation Research Procedia, 22, 25-34 (2017) https://doi.org/10.1016/j.trpro.2017.03.004

10 A.S. Romanenko, A.P. Kuznetsova, V.V. Kas'yanenko, D.A. Madzhar, Nauchnyye trudy Severo-Kavkazskogo zonal'nogo nauchno-issledovatel'skogo instituta sadovodstva i vinogradarstva, 9, 150-155 (2016) https://www.elibrary.ru/item.asp?id=26184231

11 J.N. Robinson, O.B. Olubukola, International Journal of Phytoremediation, 18 (2), 200209 (2016) https://doi.org/10.1080/15226514.2015.1073671 
12 Z. Hoshyar, B. Abedi, E.G. Moghadam, G.D. Nejad, Journal of Plant Physiology and Breeding, 7(1), P. 53-60 (2017) https://www.researchgate.net/profile/Ebrahim_Ganji_moghadam/publication/344782285_E ffect_of_Arbuscular_Mycorrhiza_on_Growth_and_Physiological_Behavior_of_PHLC_Rootstock/links/5f8fee0d299bf1b53e379e26/Effect-of-Arbuscular-Mycorrhiza-onGrowth-and-Physiological-Behavior-of-PHL-C-Rootstock.pdf 13 A. Puri, Kiran P. Padda, C. P.Chanwaya, Applied Soil Ecology, 149, (2020) https://doi.org/10.1016/j.apsoil.2020.103538

14 L. Vettori, A. Russo, C. Felici, G. Fiaschi, S. Morini, A. Toffanin, Journal of Plant Interactions, 5(4), 249-259 (2010) https://doi.org/10.1080/17429145.2010.511280

15 S. Głuszek, E. Derkowska, L. Sas Paszt, M. Sitarek, B. Sumorok, Hort. Sci. (Prague), 47, 122-129(2020). https://doi.org/10.17221/102/2018-HORTSCI

16 M. O’Callaghan, Appl. Microbiol. Biotechnol., 100, 5729-5746 (2016). https://doi.org/10.1007/s00253-016-7590-9

17 A. Fatemeh, T. Masoud, A. Pejman, H. Aidin, Pojark. Seeds Scientia Horticulturae, 172 (9), 61-67(2014) https://doi.org/10.1016/j.scienta.2014.03.049

18 A.P. Kuznetsova, A.I. Drygina, S.N. Shcheglov, S.I. Gridnev, Nauchnyye trudy SeveroKavkazskogo federal'nogo nauchnogo tsentra sadovodstva, vinogradarstva, vinodeliya, 23, 70-76 (2019) https://doi.org/10.30679/2587-9847-2019-23-70-76 